\title{
Role of microRNAs in hepatocellular carcinoma: a clinical perspective
}

This article was published in the following Dove Press journal:

OncoTargets and Therapy

29 August 2013

Number of times this article has been viewed

\author{
Elisa Callegari' \\ Bahaeldin K Elamin ${ }^{1,2}$ \\ Silvia Sabbioni ${ }^{3,5}$ \\ Laura Gramantieri ${ }^{4}$ \\ Massimo Negrini ${ }^{1,5}$ \\ 'Dipartimento di Morfologia, \\ Chirurgia e Medicina Sperimentale, \\ Università di Ferrara, Ferrara, Italy: \\ ${ }^{2}$ Department of Microbiology, Faculty \\ of Medical Laboratory Sciences, \\ University of Khartoum, Sudan; \\ ${ }^{3}$ Dipartimento di Scienze della Vita e \\ Biotecnologie, Università di Ferrara, \\ Ferrara, ${ }^{4}$ Centro di Ricerca Biomedica \\ Applicata e Dipartimento di Medicina \\ Interna, Policlinico S Orsola-Malpighi \\ e Università di Bologna, Bologna, \\ ${ }^{5}$ Tecnopolo "Laboratorio per le \\ Tecnologie delle Terapie Avanzate", \\ Università di Ferrara, Ferrara, Italy
}

Correspondence: Massimo Negrini

Dipartimento di Morfologia, Chirurgia

e Medicina Sperimentale, Università

di Ferrara, via Luigi Borsari 46, 44I2I,

Ferrara, Italy

Tel +39053245 5399

Fax +39053245 5875

Email ngm@unife.it

\begin{abstract}
Hepatocellular carcinoma (HCC) is one of the most deadly tumors, and current treatments for the disease are often ineffective. The discovery of the involvement of microRNAs (miRNAs) in hepatocarcinogenesis represents an important area of investigation for the development of their clinical applications. These molecules may act as oncogenes or tumor suppressors by directly or indirectly controlling the expression of key proteins involved in cancer-associated pathways. On the clinical side, because of their tumor-specific expression and stability in tissues and in the circulation, miRNAs have been proposed as novel diagnostic tools for classification and prognostic stratification of HCC. In recent years, the therapeutic potential of miRNAs has been demonstrated in various preclinical studies. Anti-miRNA oligonucleotides and miRNA mimics have been found to have antitumor activity. Moreover, by exploiting tumor-specific expression of miRNA, efforts have been aimed at improving targeting of tumor cells by replicative oncolytic viruses while sparing normal cells. These areas are expected to be explored further in the upcoming years to assess the clinical value of miRNA-based approaches in $\mathrm{HCC}$ and cancer in general.
\end{abstract}

Keywords: hepatocellular carcinoma, microRNA, micromarkers, oncolytic viruses

\section{Introduction}

Hepatocellular carcinoma (HCC), the most common primary liver cancer, is one of the most prevalent malignant diseases worldwide, and the third most common cause of cancer-related deaths. ${ }^{1}$ In spite of the development of novel therapeutic strategies, the prognosis of advanced HCC remains poor, with a life expectancy of about six months from the time of diagnosis. ${ }^{2}$ In most cases, HCC originates on a background of cirrhosis, ${ }^{3}$ a chronic and diffuse hepatic disease that results from continuous liver injury and regeneration. Increased hepatocyte turnover, inflammation, and oxidative DNA damage are implicated in the pathogenesis of the disease. The prevalent risk factors for HCC are also the cause of liver cirrhosis, and include viral infections (eg, hepatitis B and C) and alcohol consumption; further risk factors include tobacco smoking, exposure to aflatoxin B1 and vinyl chloride, diabetes, and genetic disorders, such as hemochromatosis and alpha-1 antitrypsin deficiency. ${ }^{4-9}$

$\mathrm{HCC}$ is a cancer with a poor prognosis because of the low proportion of cases amenable to curative treatment at diagnosis and the high rate of recurrence following therapeutic intervention. The estimated recurrence rate can be as high as $70 \%-80 \%$ at five years, considering both true recurrences and $\mathrm{HCC}$ de novo, and this contributes significantly to the dismal prognosis of HCC. In addition, traditional therapies are not effective for $\mathrm{HCC}$ and are too toxic for patients with cirrhosis. Transarterial chemoembolization and 
radioembolization are the main treatments for intermediatestage $\mathrm{HCC}$ at the present time. ${ }^{10}$ The only systemic therapy available for advanced HCC is based on the multikinase inhibitor sorafenib, ${ }^{11}$ which is the most effective therapeutic tool for advanced nonresectable HCC, in which it can slightly improve patient survival. ${ }^{12,13}$ The survival of patients with advanced HCC treated with sorafenib depends on the absence of liver dysfunction and on the status of the patient. ${ }^{14,15}$ In the past few years, use of sorafenib in combination with transarterial chemoembolization has significantly improved survival rates in patients with advanced HCC. ${ }^{16,17}$ New perspectives in cancer treatment have appeared recently with the advent of the microRNAs (miRNAs), a novel class of noncoding small RNAs.

\section{microRNAs}

microRNAs are short RNAs (containing 20-24 nucleotides) that play an important role in all biological processes by post-transcriptional regulation of protein-coding genes. ${ }^{18}$ They constitute a large class of phylogenetically conserved genes, with more than 2000 miRNAs having been discovered in humans. ${ }^{19}$ miRNAs are transcribed by RNA polymerase II to produce a primary pre-miRNA, cleaved by the DroshaDGCR 8 complex to a shorter pre-miRNA approximately 70 nucleotides long. The pre-miRNA is transported by Exportin-5/RanGTP from the nucleus to the cytoplasm, where it is processed to a short miRNA-miRNA*-duplex by the DicerTRPB complex. The *strand is usually degraded, and the other strand becomes the mature miRNA that is incorporated into the RNA-induced silencing complex.

This ribonucleoprotein complex eventually becomes bound to regions of homology present in messenger RNAs (mRNAs), usually within their $3^{\prime}$ untranslated regions. Recruitment of the RNA-induced silencing complex to the target mRNA can promote either degradation or repression of translation. Via these mechanisms, each miRNA can modulate the expression of target protein-coding genes (reviewed recently by Davis-Dusenbery and Hata ${ }^{20}$ and Farazi et $\mathrm{al}^{21}$ ). Each miRNA can promote the targeting and modulation of expression of tens or even hundreds of mRNAs. On the other hand, each mRNA can be targeted and under the control of several miRNAs. It has also become evident that mRNAs or RNAs highly expressed by pseudogenes or long noncoding RNAs can act as a "sponge" to reduce interaction between miRNAs and other mRNA species. Therefore, the network of interactions between mRNA and miRNA is complex and largely still to be clarified in a comprehensive systemic fashion.

\section{Role of miRNAs in cancer}

In view of their role in regulating the expression of proteincoding genes, miRNAs now have a widely recognized role in human carcinogenesis. Initial evidence came from detection of their aberrant expression in all human cancers. ${ }^{22}$ Some of them are frequently found to be upregulated or downregulated in cancer in comparison with normal tissue. There is now mounting experimental evidence indicating that they may act as oncogenes or tumor suppressors by disrupting regulation of genes encoding for oncoproteins and tumor suppressor proteins. $^{23}$

In vivo models have provided conclusive proof that miRNAs play a key role in tumorigenesis. Proof of principle of the involvement of miRNA in the development of neoplastic disease was provided by generation of the E $\mu$-miR 155 transgenic mouse that develops a lymphoproliferative B-cell malignancy. ${ }^{24}$ Further animal models confirmed that deregulated miRNAs could be involved in tumorigenesis in vivo, mostly in hematologic malignancies. ${ }^{25-28}$ Targeted deletions demonstrated this functional activity in putative tumor suppressor miRNAs; for example, a miR-15a/miR16-1 knockout mouse model is predisposed to development of an indolent form of leukemia, resembling human chronic lymphocytic leukemia, where deletion of these miRNAs is found in over $60 \%$ of cases. ${ }^{29}$

\section{Role of specific miRNAs in HCC}

Involvement of miRNAs in HCC has been demonstrated, as in other cancers. HCC develops via deregulation of various molecular pathways, including p53, RAS/MAPK, PI3K/ AKT/mTOR, WNT/ $\beta$-catenin, MET, MYC, and transforming growth factor beta. Genetic and epigenetic alterations, as well as aberrant miRNA expression, can affect these crucial cancer-associated pathways (for a detailed review, see Negrini et $\left.\mathrm{al}^{30}\right)$.Several studies have shown that expression of miRNA is deregulated in $\mathrm{HCC}$ in comparison with normal liver tissue (again, see Negrini et $\mathrm{al}^{30}$ for a comprehensive review). In light of reports from independent studies, consistent deregulation of miR-122, miR-199, miR-221, and miR-21 appears to be particularly important in HCC (Figure 1). Interestingly, both miR-122 and miR-199a are among the miRNAs most highly expressed in the normal liver. ${ }^{31}$

miR-122 is unique among the deregulated miRNAs, in that it is almost exclusively expressed physiologically in the adult liver, ${ }^{32}$ where it appears to act as a key regulator of the differentiation of adult hepatocytes via repression of genes not specific to the liver. ${ }^{33-35}$ At the molecular level, this effect is achieved by regulation of CUTL1, a transcriptional repressor 


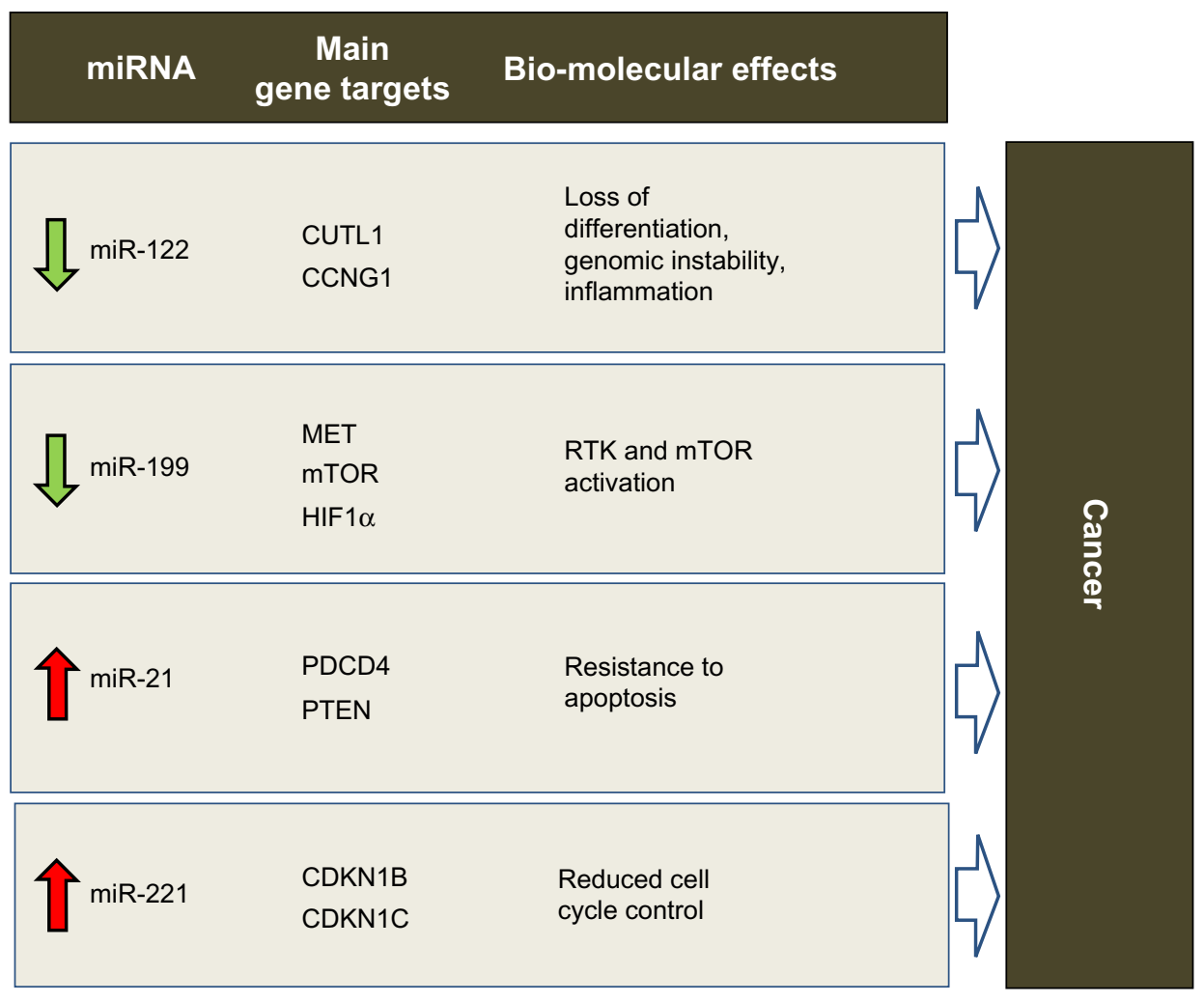

Figure I Predicted effects of deregulated miRNAs in hepatocarcinogenesis. miR-|22, miR-199, miR-22I and miR-2I were shown by various studies to be consistently deregulated in HCC. Via aberrant control of protein-coding gene targets (only the major ones are shown), their deregulation is expected to induce biomolecular effects that promote tumorigenesis.

Abbreviations: miRNA, microRNA; HCC, hepatocellular carcinoma.

of genes specifying terminal differentiation in multiple cell lineages, including hepatocytes. CUTL1 was shown to be the most prominent repressed target of miR-122. ${ }^{33}$ In HCC, miR-122 is downregulated in approximately $70 \%$ of cases, suggesting a tumor suppressor function for this miRNA. Various lines of evidence now support this hypothesis. Enforced expression of miR-122 can induce apoptosis and arrest of the cancer cell cycle, ${ }^{36,37}$ inhibit tumorigenicity in liver cancer cell lines in vivo, ${ }^{36}$ and sensitize cells to sorafenib or doxorubicin. ${ }^{36,38}$ In addition, loss of miR-122 expression in patients with liver cancer is correlated with the presence of metastasis ${ }^{39,40}$ and a shorter time to recurrence. ${ }^{38}$ The role of miR-122 in liver cancer has been demonstrated directly by the generation of miR-122 knockout mice. ${ }^{41,42}$ These mice were characterized by hepatic inflammation, fibrosis, and development of spontaneous tumors similar to HCC, demonstrating the tumor-suppressor function of this miRNA and its important role in liver metabolism and differentiation of hepatocytes. These phenotypic effects could at least in part be understood by identification of miR-122 gene targets. Reduced control of CUTL1, as previously mentioned, may be responsible for the lack of differentiation that characterizes $\mathrm{HCC}$ cells. Another known target of miR-122 is cyclin G1, ${ }^{43}$ which is a negative regulator of p53 and is frequently upregulated in HCC. In a mouse model, the absence of cyclin G1 was associated with less susceptibility to developing liver tumors. ${ }^{44}$ Reduced levels of miR-122 could lead to inhibition of p53 activity by increasing cyclin G1 levels. ${ }^{38}$ Loss of miR-122 could also directly affect the intrinsic apoptotic pathway by reduced regulation of the antiapoptotic protein, Bcl-w. ${ }^{45}$ miR-122 invasive and metastatic properties were instead linked to loss of control on ADAM17 (a disintegrin and member of the metalloproteinase family) ${ }^{39}$ By targeting ADAM17, miR-122 can reduce in vitro migration and invasion, in vivo tumorigenesis and angiogenesis, and local invasion in the livers of nude mice. A similar effect could also be expected when targeting ADAM10. ${ }^{36}$

miR-199 has been reported to be consistently downregulated in the majority of HCC, ${ }^{43,46,47}$ suggesting a tumor suppressive function. All three members of the miR-199 family, ie, miR-199a-1, miR-199a-2, and miR-199b, have emerged as being frequently downregulated in HCC. Phenotypically, enforced expression of miR-199a in HCC cells leads to cell cycle arrest at G1 phase, reduced invasive capability, and enhanced susceptibility to hypoxia. In patients with HCC, downregulation of miR-199a was associated with a higher 
recurrence rate and shorter time to recurrence after surgery. These effects could be explained by modulation of target genes, such as MET, mTOR, and HIF- $1 \alpha \cdot{ }^{48-51}$ Another important target of miR-199 in HCC is CD44, a transmembrane glycoprotein involved in cell-cell interaction, cell adhesion, and migration. ${ }^{52}$ Further, absence of control over Discoidin domain receptor-1 tyrosine kinase may promote cell invasion processes in HCC. ${ }^{53}$

Among the miRNAs that are upregulated in HCC, there is evidence in support of the tumor-promoting activity of miR-221. It is upregulated in $70 \%-80 \%$ of HCC samples. ${ }^{54}$ From a functional point of view, HCC cells overexpressing miR-221 show increased growth, proliferation, migration, and invasion capability. ${ }^{54-56}$ miR-221 antagomirs inhibit growth of liver cancer cells, and enforced miR-221 expression was shown to enhance tumorigenesis of cells when implanted in mice. In this setting, overexpression of miR-221 promotes tumor progression and shortens the survival of the animal. ${ }^{57}$ More recently, a transgenic mouse model characterized by overexpression of miR-221 in the liver was developed. This model demonstrates high susceptibility to HCC in male animals, which can be partly inhibited by challenge with anti-miR-221 oligonucleotides. ${ }^{58}$ By modulating multiple gene targets, miR-221 has been shown to affect several cancer pathways. The cell cycle could be promoted by modulation of the cyclin-dependent kinase inhibitors, CDKN1B/p27 and CDKN1C/p57. ${ }^{54}$ Other important targets include the $\mathrm{BH} 3$-only protein, Bcl2-modifying factor ${ }^{59}$ (a proapoptotic protein) and PTEN (a negative regulator in the PI3K-AKTmTOR pathway). ${ }^{56}$ DNA damage-inducible transcript 4 , another negative regulator of the mTOR pathway, was also identified as a target of miR-221. ${ }^{57} \mathrm{miR}-221$ was also shown to affect invasion and metastasis by controlling TIMP3, a tissue inhibitor of metalloproteases. ${ }^{56}$ These examples outline the importance of deregulation of even a single miRNA in cancer. miR-221 is a paradigmatic example of an miRNA regulating multiple pathways at one time.

miR-2 1 is a potent oncogene when upregulated. It is overexpressed in HCC as well as in several other human malignancies, including breast, colon, lung, pancreas, prostate, and stomach cancers. ${ }^{60}$ Overexpression of miR-21 in cultured human cells can protect against apoptosis ${ }^{61}$ and increase tumor cell proliferation and migration. ${ }^{62}$ In vivo, miR-21 inhibition suppressed cell proliferation and increased apoptosis in a cancer xenograft model. ${ }^{62}$ In a transgenic mouse model, overexpression of miR-21 led to a pre-B malignant lymphoma that regressed completely when miR-21 was inactivated, partly as a result of apoptosis. ${ }^{28}$ Another important activity of miR-21 is chemoresistance induced against a variety of anticancer compounds. These multiple effects are linked to several genes targeted by miR-21 (for a recent review describing miR-21 target genes, see Buscaglia and $\left.\mathrm{Li}^{63}\right)$. Among the most important of these is PTEN, ${ }^{64}$ which promotes cell survival via activation of the PI3K-AKT pathway, and tumor suppressor programmed cell death $4,65,66$ a protein believed to have a role in apoptosis induced by transforming growth factor-beta.

\section{Clinical implications miRNA diagnostics}

Profiling of miRNA expression could be a useful tool for classification purposes and for improving prognostic stratification. Previous reviews have summarized the potential applications of miRNAs as diagnostic and prognostic markers in human cancer and in particular liver cancer. ${ }^{30,67,68}$

Several miRNAs may have potential prognostic significance. Table 1 summarizes the presently available data. For classification purposes, it is shown that miR-200c, miR-141 and miR-126, alone or in combination, could be used to distinguish primary $\mathrm{HCC}$ versus other tumor metastases to the liver with very high accuracy; moreover, the ratio of miR-205 to miR-194 expression could be used to distinguish between gastrointestinal tumors and metastases outside the gastrointestinal system, ${ }^{69}$ which is important considering that the liver is the main metastatic site for gastrointestinal tumors. ${ }^{70}$

An emerging area of investigation with regard to miRNAs is their potential use as circulating biomarkers. Because of their different levels in the serum or plasma of patients affected by a range of diseases in comparison with healthy subjects, ${ }^{71}$ miRNAs could be useful biomarkers for patient follow-up. ${ }^{72}$ Table 2 summarizes the studies of miRNAs in serum and plasma, confirming the potential use of miRNAs as sensitive markers for detection of an underlying $\mathrm{HCC}$ and for prognostic stratification of the disease. Among the miRNAs, miR-122 and miR-21 levels have been reported by more than one study to be significantly higher in patients with HCC. Because increased levels are also detected in chronic hepatitis, their usefulness as clinical tumor markers needs to be validated further. ${ }^{73-77}$

Overall, these results point to miRNAs being potential biomarkers that could improve our ability to stratify the prognosis and monitor follow-up in patients with HCC. Their stability in formalin-fixed and paraffin-embedded samples as well as in body fluids like serum or plasma is an important property for enabling their detection and quantification in biological samples, which are frequently used in clinical 
Table I microRNAs with potential prognostic impact in patients with HCC

\begin{tabular}{|c|c|c|c|}
\hline miRNAs & Molecular alteration & Clinical significance & Reference \\
\hline 20 miRNAs & Signature & Venous metastasis, overall survival & $|3|$ \\
\hline 19 miRNAs & Signature & Poor survival & 47 \\
\hline $\begin{array}{l}\text { miR-19a, miR-886-5p, miR-126, } \\
\text { miR-223, miR-24 and miR-147 }\end{array}$ & Signature & Predictor of overall survival and recurrence-free survival after LT & 132 \\
\hline miR-26a & Downregulation & Poor survival & 133 \\
\hline miR-I22 & Downregulation & Gain of metastatic properties & 39,40 \\
\hline miR-I22 & Downregulation & Early recurrence & 38 \\
\hline Let-7 members & Downregulation & Early recurrence & 134 \\
\hline miR-199a-3p & Downregulation & Reduced time to recurrence & 49 \\
\hline miR-199b-5p & Downregulation & Poor overall survival and progression-free survival rates & 51 \\
\hline miR-I0I & Downregulation & Advanced tumor progression, poor prognosis & 135 \\
\hline miR-125a & Upregulation & Better survival & 136 \\
\hline miR-92, miR-20, miR-I8 & Upregulation & Poor differentiation & 46 \\
\hline miR-372 & Upregulation & Advanced TNM stage & 137 \\
\hline miR-22I & Upregulation & Multinodularity, reduced time to recurrence & 59 \\
\hline miR-22I & Upregulation & Gain of metastatic properties & 138 \\
\hline miR-22I & Upregulation & High tumor capsular infiltration & 139 \\
\hline miR-I7-5p & Upregulation & Multiple tumor nodules, vein invasion, shortened overall survival & 140 \\
\hline miR-I55 & Upregulation & High recurrence and poor prognosis following OLT & 141 \\
\hline miR-203 & Upregulation & Good prognosis & 142 \\
\hline miR-18 & Upregulation & Poor prognosis & 143 \\
\hline
\end{tabular}

Abbreviations: HCC, hepatocellular carcinoma; miRNAs, microRNAs; TNM, tumor-node-metastasis; LT, liver transplantation; OLT, orthotopic liver transplantation. Note: Data adapted from Negrini et al. ${ }^{30}$

assays. However, at present, prospective studies are still required before miRNAs can be used in the clinic as biomarkers for cancer.

\section{miRNA therapeutics miRNA inhibition}

In the past few years, several lines of evidence have indicated that strategies based on modulation of miRNA activity could be a novel approach to treating cancer (Figure 2). In 2005, Krutzfeldt et al showed that intravenous administration of specific antagomirs could silence miR-122 in the mouse liver. ${ }^{78} \mathrm{~A}$ few years later, Elmen et al demonstrated that inhibition of miR-122 by administration of anti-miRNA oligonucleotides in nonhuman primates was a promising approach for reducing miRNA activity in the adult liver without any evidence of toxicity. ${ }^{79}$ These proofs of principle established the basis for the various studies that have been performed in cancer models in vivo.

Anti-miR-221 was shown to have antitumor activity, which was demonstrated by intratumoral injections of antimiRNA oligonucleotides into prostate carcinoma cell-derived tumors, ${ }^{80}$ in melanoma cell xenotransplants, ${ }^{81}$ and in multiple myeloma xenografts. ${ }^{82}$ Park et al showed the ability of antimiR-221 molecules to reduce proliferation of tumor cells and promote survival in an orthotopic mouse model of HCC. ${ }^{83}$ Anti-miR-221 was also shown to downregulate miR-221 levels in the liver of the miR-221 transgenic mouse and to achieve a significant reduction in the number and size of tumors in comparison with untreated animals. ${ }^{58}$

The role of the miR-21 oncomir was investigated using anti-miR-21 molecules in vivo. Use of anti-miR-21 led to complete regression of pre-B lymphoid-like malignancies in mice overexpressing miR-21. ${ }^{28}$ Anti-miR-21 was also reported to have significant antitumor activity in SCID mice bearing human multiple myeloma xenografts. ${ }^{84}$ Thus, by confirming the feasibility as well as short-term safety and efficacy of these molecules in large-scale preclinical settings, these studies established the basis for the use of anti-miRNAs in clinical trials.

The first miRNA-targeted drug, a molecule known as miravirsen SPC3649, has been used in various Phase I investigations and is currently in a Phase II clinical trial for the treatment of hepatitis $\mathrm{C}$ virus (HCV) infection. ${ }^{85}$ This trial stems from the discovery of involvement of miR-122 in HCV RNA accumulation, and demonstrated that treatment of chronically infected nonhuman primates with an LNAmodified anti-miR-122 oligonucleotide was well tolerated and led to long-lasting suppression of HCV viremia. ${ }^{86,87}$

\section{miRNA replacement}

In addition to inhibition of oncomirs, another approach to treating cancer is based on restoration of tumor suppressor miRNAs. Several examples of this approach 
Table 2 Circulating microRNAs in liver disease

\begin{tabular}{|c|c|c|c|c|}
\hline miRNAs & Sample & Clinical condition & Clinical relevance & Reference \\
\hline miR-I22 & Serum & $\begin{array}{l}\text { High levels in patients with HCC or chronic } \\
\text { hepatitis; lower levels in severe stages of fibrosis }\end{array}$ & $\begin{array}{l}\text { Biomarker for liver injury but not specific } \\
\text { for } \mathrm{HCC} \text {; indicator of fibrosis progression in } \\
\mathrm{CHC} \text { infection; marker to distinguish patients } \\
\text { with } \mathrm{CHC} \text { from healthy controls }\end{array}$ & $\begin{array}{l}74,76,77 \\
144,145\end{array}$ \\
\hline miR-2I & $\begin{array}{l}\text { Serum/ } \\
\text { plasma }\end{array}$ & $\begin{array}{l}\text { High levels in patients with HCC or chronic } \\
\text { hepatitis; higher levels in patients with HCC than in } \\
\text { those with chronic hepatitis or healthy volunteers }\end{array}$ & $\begin{array}{l}\text { Biomarker for liver injury but not specific } \\
\text { for HCC; biochemical marker for HCC }\end{array}$ & $73-75,146$ \\
\hline miR-223 & Serum & High levels in patients with $\mathrm{HCC}$ or chronic hepatitis & $\begin{array}{l}\text { Biomarkers for liver injury but not specifically } \\
\text { for HCC }\end{array}$ & 73 \\
\hline miR-885-5p & Serum & High levels in patients with HCC, LC, or CHB & $\begin{array}{l}\text { Complementary biomarker for detection } \\
\text { and assessment of liver pathologies }\end{array}$ & 147 \\
\hline $\begin{array}{l}\text { miR-16 } \\
\text { miR-34a }\end{array}$ & Serum & Higher levels in patients with NAFLD than in controls & $\begin{array}{l}\text { Correlation with liver enzymes levels, fibrosis } \\
\text { stage, and inflammation activity; biomarkers } \\
\text { of diagnosis and histological disease severity } \\
\text { in patients with CHC or NAFLD }\end{array}$ & 74 \\
\hline $\operatorname{miR}-221$ & Serum & $\begin{array}{l}\text { High levels correlated with tumor size, cirrhosis, } \\
\text { and tumor stage }\end{array}$ & $\begin{array}{l}\text { Predictive significance for prognosis of } \\
\text { patients with } \mathrm{HCC}\end{array}$ & 146 \\
\hline $\begin{array}{l}\text { miR-I5b } \\
\text { miR-I30b }\end{array}$ & Serum & $\begin{array}{l}\text { Higher levels in tumors during the exploration } \\
\text { phase on resected tumor/adjacent and nontumor } \\
\text { tissues; lower levels after surgery }\end{array}$ & $\begin{array}{l}\text { Biomarker with clinical value for } \mathrm{HCC} \\
\text { screening }\end{array}$ & 148 \\
\hline $\begin{array}{l}\text { miR-20a } \\
\text { miR-92a }\end{array}$ & $\begin{array}{l}\text { Plasma/ } \\
\text { serum }\end{array}$ & $\begin{array}{l}\text { High levels in HCV-infected patients with fibrosis compared } \\
\text { with healthy volunteers or liver disease not associated } \\
\text { with HCV; higher levels in acute and chronic HCV-infected } \\
\text { patients as compared with healthy volunteers }\end{array}$ & $\begin{array}{l}\text { Biomarkers for early detection of HCV } \\
\text { infection; miR-20a is a predictive biomarker } \\
\text { of HCV-mediated fibrosis }\end{array}$ & 149 \\
\hline
\end{tabular}

Abbreviations: HCC, hepatocellular carcinoma; CHC, chronic hepatitis C; CHB, chronic hepatitis B; LC, liver cirrhosis; NAFLD, nonalcoholic fatty liver disease; HCV, hepatitis $C$ virus; miRNAs, microRNAs.

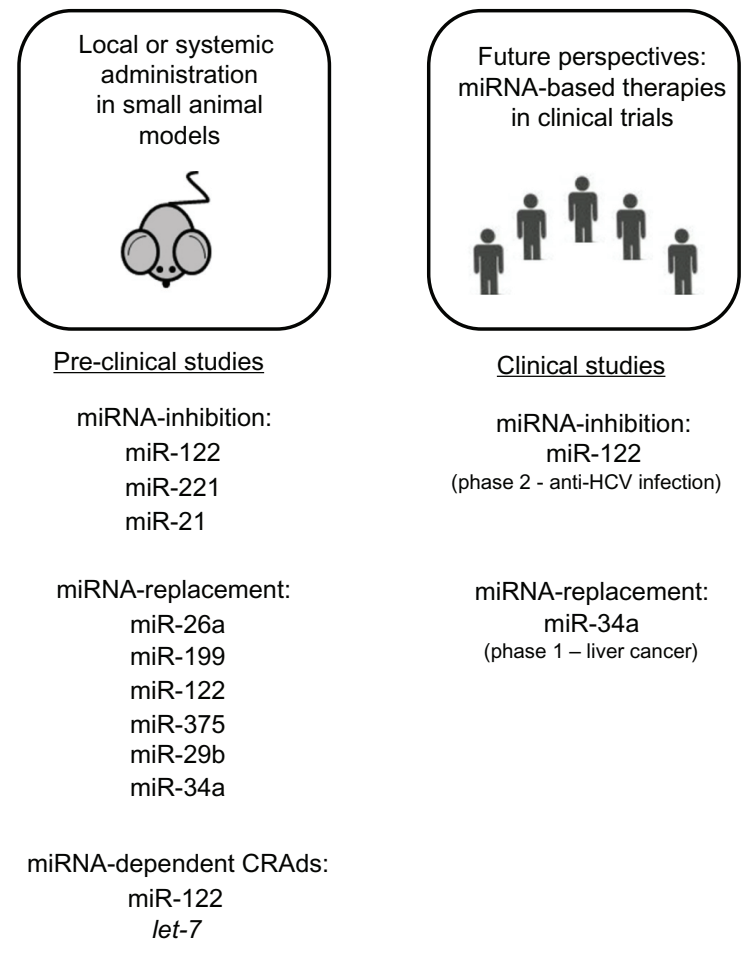

Figure 2 Therapeutic strategies based on modulation of miRNA activity. Summary of preclinical studies (on the left) based on miRNA inhibition, miRNA replacement, and conditionally replicating adenoviruses regulated by miRNA (microRNA) target elements. On the right are clinical trials ongoing using miRNA-based drugs. already exist. Enforced expression of miR-26a using an adenoassociated (AAV8) delivery system inhibited tumorigenicity in a myc mouse HCC model ${ }^{88}$ Both AAV8 miR-199 and cholesterol conjugated small RNA delivery systems could effectively restore miR-199a/b-3p and reduce tumor size in HCC xenografts..$^{31}$ The tumor suppressor role of miR-122 in HCC was confirmed by strong inhibition of tumorigenesis using AAV-mediated delivery of miR-122 in a myc mouse HCC model. ${ }^{41}$ Administration of cholesterol-conjugated 2'-O-methyl-modified miR-375 mimics significantly suppressed growth of hepatoma xenografts in nude mice. $.^{89} \mathrm{miR}-$ 29b could sensitize HCC cells to various apoptotic signals and could suppress the ability of HCC cells to form tumors in nude mouse xenograft models. ${ }^{90}$

Further studies demonstrating the antitumor effectiveness of miRNAs have been reported in other types of tumors and experimental settings. ${ }^{91-93}$ An important example is restoration of miR-31, the action of which could alter the invasive properties of disseminated tumor cells, raising the possibility of developing miRNA-based strategies for the treatment of metastatic disease. ${ }^{94}$

The above studies establish miRNAs as promising molecules in cancer therapy. In this context, miR-34a is the first miRNA mimic to reach the clinic (http://clinicaltrials.gov/ 
ct2/show/NCT01829971).${ }^{95}$ Earlier studies showed that lentivirus expressing miR-34a could prevent tumor formation and progression in mouse models of lung adenocarcinoma induced by K-ras and p53. ${ }^{96}$ Inhibition of tumor growth and increased survival were also observed in mice bearing multiple myeloma xenografts treated with miR-34a mimics. ${ }^{97}$ Very recently, expression of miR-34 combined with the cytokine interleukin-24 showed synergistic antitumor activity in a xenograft model of HCC, indicating the possibility of using a multiple-armed miRNA-based viral vector in cancer therapy. ${ }^{98}$

\section{Oncolytic viruses}

Oncolytic viruses are developed to replicate selectively in tumor cells. They are engineered to have cytotoxic effects in tumor cells with minimal toxicity in normal cells. For this reason, they hold promise for the treatment of cancer. ${ }^{99-101}$ The first conditionally replicating adenovirus (CRAd), known as ONYX-015, carried a deletion in the E1B-55 kDa coding region, which was designed to limit its replication with cells having dysfunctional $\mathrm{p} 53 .{ }^{99}$ It was used in clinical trials either alone or in combination with chemotherapeutic agents. ${ }^{102-107}$ Since then, progress has been made in this field, with more selective and potent oncolytic viruses having been entered into clinical trials (see Patel and Kratzke ${ }^{108}$ for a recent review).

Among the oncolytic viruses in use, the presence of the gene for the immune stimulator granulocyte-macrophage colony-stimulating factor (GM-CSF) is improving significantly antitumor activity. The safety and biological activity of an oncolytic viral vector based on herpes simplex virus type-1, known as OncoVEX ${ }^{\mathrm{GM}-\mathrm{CSF}}$ (Amgen, Thousand Oaks, CA, USA), has been assessed in several clinical trials. ${ }^{109,110}$ Oncolytic adenoviruses armed with GM-CSF have also been used successfully in the treatment of patients with advanced metastatic tumors refractory to conventional therapies. Their use resulted in antitumor immunity and increased median overall survival. ${ }^{111-113}$ Oncolytic poxvirus carrying GM-CSF was also investigated in clinical trials, and demonstrated an oncolytic and immunotherapeutic mechanism of action, tumor responses, and dose-related survival in treated patients with HCC. ${ }^{114-116}$

To generate safer oncolytic viruses, miRNA-mediated suppression of virus replication has been used successfully to reduce pathogenic effects in normal tissue. The cellular tropism of a picornavirus was modulated by engineering target sequences for muscle-specific miRNAs into the viral genome, thereby avoiding development of lethal myositis in tumor-bearing mice. ${ }^{117}$ Ylosmaki et al developed a new type of conditionally replicating CRAd regulated by miR122 target elements within the $3^{\prime}$ untranslated regions of the E1A gene, achieving liver-specific suppression of viral replication and reducing hepatotoxicity. ${ }^{118}$ At the same time, it was found that viral oncolytic activity was not damaged in targeted tumors in vivo. ${ }^{119} \mathrm{~A}$ similar approach has been reported by Cawood et al, who showed that incorporation of miR-122-binding sites to control E1A mRNA significantly reduced adenoviral replication and liver toxicity in mice. ${ }^{120,121}$ Another approach to E1A regulation combines an miR-122 control with chromogranin-A gene promotercontrolled virus replication, allowing use of high doses of adenovirus for more effective tumor treatment with limited liver toxicity. ${ }^{122}$ Other miRNAs involved in the control of oncolytic virus replication include a let-7-dependent oncolytic adenovirus, which is able to replicate only in cells lacking miRNA expression, such as HCC cells, and not in normal liver cells. ${ }^{123}$

These reports have established the potential value of engineered oncolytic viruses in the treatment of human malignancy. In this context, the target sequences of miRNAs could ensure the detargeting from normal tissues of virus replication, which still remains active in tumor cells.

In human cancer, most of the malignant cells are unable to produce tumors when implanted into immunodeficient mice. Still, $1 \%-2 \%$ of these cells maintain cell renewal capabilities and may generate tumors. It has been suggested and demonstrated in several instances that these cells persist in tumors as distinct populations, which are designated as tumor-initiating cells or cancer stem cells. ${ }^{124}$ Cancer stem cells are essential for the growth of solid tumors and hematologic malignancies, as well as for seeding of metastases. Because they consist largely of nonproliferating cells, they are also intrinsically resistant to traditional therapies, thereby being responsible for relapses following therapy. Hence, it has been suggested that effective therapies against cancer stem cells could potentially lead to complete eradication of tumors.

Several studies have demonstrated the importance of miRNAs in the control of stem cells ${ }^{125,126}$ as well as the phenotype of the cancer stem cell. ${ }^{124}$ In HCC, identification of a cell population called CD133+ which has the characteristics of cancer stem cells, has provided new perspectives for characterization of liver cancer. ${ }^{127}$ Several lines of evidence indicate that aberrant expression of miRNAs may control and lead to maintenance of liver tumor-initiating cells through aberrant modulation of stem cell-associated genes. 
Table 3 microRNAs and cancer stem cells in HCC

\begin{tabular}{|c|c|c|}
\hline miRNAs & Regulatory role in liver cancer stem cells & Reference \\
\hline miR-I8I & $\begin{array}{l}\text { Maintenance of EPCAM + AFP + HCC cells by inhibiting hepatic cell differentiation and promoting } \\
\mathrm{HCC} \text { stemness through targeting the transcriptional regulators CDX2 and GATA6 as well as the } \\
\text { Wnt signaling inhibitor, NLK }\end{array}$ & $|50,15|$ \\
\hline miR-193b & Regulation of proliferation, migration, and invasion potential of HCC cells by downregulation of ETSI & 152 \\
\hline miR-I30b & Promotion of tumor growth and self-renewal in CDI33+ T-ICs by downregulation of TP53INPI & 153 \\
\hline miR-I22 & $\begin{array}{l}\text { Modulation of self-renewal of hESCs and HCC proliferation by suppressing translation of the metabolic } \\
\text { protein PKM2 }\end{array}$ & 154 \\
\hline miR-I45 & Modulation of downstream stem cell-related gene target Oct4 & 155 \\
\hline miR-I50 & Self-renewal of CDI33+ liver CSCs through direct negative regulation of the downstream target, c-Myb & 156 \\
\hline miR-200c & $\begin{array}{l}\text { The miR-200-controlled epithelial-mesenchymal transition is functionally important for the development of } \\
\text { stem-like cells associated with poor prognosis }\end{array}$ & 157 \\
\hline miR-2I6a; miR-2I6a/2I7 & $\begin{array}{l}\text { Overexpression of these miRNAs activates the PI3K/Akt and TGF- } \beta \text { pathways by targeting } \\
\text { PTEN and SMAD7, contributing to neoplastic transformation of LPCs to hepatic T-ICs, facilitating } \\
\text { hepatocarcinogenesis and tumor recurrence in HCC }\end{array}$ & 158,159 \\
\hline miR-2I 4 & $\begin{array}{l}\text { Silencing of miR-2I } 4 \text { modulates expression of EZH2, CTNNBI, and CDHI, increasing EpCAM+ } \\
\text { stem-like cells }\end{array}$ & 160 \\
\hline
\end{tabular}

Table 3 summarizes the findings in this area. As indicated earlier, miRNA-based approaches are potentially feasible. Targeting of cancer stem cells using an miRNA-based approach represents a novel area of investigation aimed at eradicating liver tumor-initiating cells, thereby treating HCC. ${ }^{128-130}$

\section{Conclusion}

While miRNA-based approaches are not presently used in the clinic, their potential applications are expanding in various areas of interest. Prognostic stratification, follow-up monitoring, and innovative therapeutic approaches are areas that might benefit from use of miRNAs. It should be noted that it has only been during the last 10 years that investigation of miRNAs in cancer has been initiated, and many more studies are needed to move this field forward into the clinical setting. Validation based on prospective studies of the use of miRNAs as cancer biomarkers is needed. Application of miRNA replacement or inhibition approaches need larger preclinical studies to assess their potential efficacy in specific contexts. The present knowledge, as summarized here, should form the basis of studies aimed at development of miRNA-based clinical applications.

\section{Acknowledgments}

This work was supported by grants to MN from the Italian Association for Cancer Research, the Italian Ministry of University and Research (project RBAPIIBYNP), and the University of Ferrara.

\section{Disclosure}

The authors report no financial conflicts of interests in this work.

\section{References}

1. Parkin DM, Bray F, Ferlay J, Pisani P. Global cancer statistics, 2002. CA Cancer J Clin. 2005;55(2):74-108.

2. Jemal A, Center MM, DeSantis C, Ward EM. Global patterns of cancer incidence and mortality rates and trends. Cancer Epidemiol Biomarkers Prev. 2010;19(8):1893-1907.

3. Bosch FX, Ribes J, Cleries R, Diaz M. Epidemiology of hepatocellular carcinoma. Clin Liver Dis. 2005;9(2):191-211.

4. Farazi PA, DePinho RA. Hepatocellular carcinoma pathogenesis: from genes to environment. Nat Rev Cancer. 2006;6(9):674-687.

5. Purohit V, Rapaka R, Kwon OS, Song BJ. Roles of alcohol and tobacco exposure in the development of hepatocellular carcinoma. Life Sci. 2013;92(1):3-9.

6. Wu HC, Santella R. The role of aflatoxins in hepatocellular carcinoma. Hepat Mon. 2012;12(10 HCC):e7238.

7. Uccello M, Malaguarnera G, Corriere T, Biondi A, Basile F, Malaguarnera M. Risk of hepatocellular carcinoma in workers exposed to chemicals. Hepat Mon. 2012;12(10 HCC):e5943.

8. Starley BQ, Calcagno CJ, Harrison SA. Nonalcoholic fatty liver disease and hepatocellular carcinoma: a weighty connection. Hepatology. 2010;51(5):1820-1832.

9. Dragani TA. Risk of HCC: genetic heterogeneity and complex genetics. J Hepatol. 2010;52(2):252-257.

10. Shrimal A, Prasanth M, Kulkarni AV. Interventional radiological treatment of hepatocellular carcinoma: an update. Indian J Surg. 2012;74(1): 91-99.

11. Abou-Alfa GK, Schwartz L, Ricci S, et al. Phase II study of sorafenib in patients with advanced hepatocellular carcinoma. J Clin Oncol. 2006;24(26):4293-4300.

12. Llovet JM, Ricci S, Mazzaferro V, et al. Sorafenib in advanced hepatocellular carcinoma. N Engl J Med. 2008;359(4):378-390.

13. Kane RC, Farrell AT, Madabushi R, et al. Sorafenib for the treatment of unresectable hepatocellular carcinoma. Oncologist. 2009;14(1): 95-100. 
14. Kostner AH, Sorensen M, Olesen RK, Gronbaek H, Lassen U, Ladekarl M. Sorafenib in advanced hepatocellular carcinoma: a nationwide retrospective study of efficacy and tolerability. Scientific World Journal. 2013;2013:931972.

15. Padhya KT, Marrero JA, Singal AG. Recent advances in the treatment of hepatocellular carcinoma. Curr Opin Gastroenterol. 2010;26(3): 189-195.

16. Bai W, Wang YJ, Zhao Y, et al. Sorafenib in combination with transarterial chemoembolization improves survival of unresectable hepatocellular carcinoma: a propensity-score matching study. J Dig Dis. 2013;14(4):181-190.

17. Zhao Y, Wang WJ, Guan S, et al. Sorafenib combined with transarterial chemoembolization for the treatment of advanced hepatocellular carcinoma: a large-scale multicenter study of 222 patients. Ann Oncol. March 18, 2013;24(7):1786-92.

18. Bartel DP. MicroRNAs: genomics, biogenesis, mechanism, and function. Cell. 2004;116(2):281-297.

19. Griffiths-Jones S. miRBase: microRNA sequences and annotation. Curr Protoc Bioinformatics. 2010; Chapter 12:Unit 12.9.1-10.

20. Davis-Dusenbery BN, Hata A. Mechanisms of control of microRNA biogenesis. J Biochem. 2010;148(4):381-392.

21. Farazi TA, Hoell JI, Morozov P, Tuschl T. MicroRNAs in human cancer. Adv Exp Med Biol. 2013;774:1-20.

22. Calin GA, Croce CM. MicroRNA signatures in human cancers. Nat Rev Cancer. 2006;6(11):857-866.

23. Negrini M, Ferracin M, Sabbioni S, Croce CM. MicroRNAs in human cancer: from research to therapy. J Cell Sci. 2007;120(Pt 11): 1833-1840.

24. Costinean S, Zanesi N, Pekarsky Y, et al. Pre-B cell proliferation and lymphoblastic leukemia/high-grade lymphoma in E(mu)-miR155 transgenic mice. Proc Natl Acad Sci U S A. 2006;103(18):7024-7029.

25. Santanam U, Zanesi N, Efanov A, et al. Chronic lymphocytic leukemia modeled in mouse by targeted miR-29 expression. Proc Natl Acad Sci US A. 2010;107(27):12210-12215.

26. Enomoto Y, Kitaura J, Hatakeyama K, et al. Emu/miR-125b transgenic mice develop lethal B-cell malignancies. Leukemia. 2011;25(12): 1849-1856.

27. Zhao JL, Rao DS, Boldin MP, Taganov KD, O'Connell RM, Baltimore D. NF-kappaB dysregulation in microRNA-146a-deficient mice drives the development of myeloid malignancies. Proc Natl Acad Sci U S A. 2011;108(22):9184-9189.

28. Medina PP, Nolde M, Slack FJ. OncomiR addiction in an in vivo model of microRNA-21-induced pre-B-cell lymphoma. Nature. 2010;467(7311):86-90.

29. Klein U, Lia M, Crespo M, et al. The DLEU2/miR-15a/16-1 cluster controls B cell proliferation and its deletion leads to chronic lymphocytic leukemia. Cancer Cell. 2010;17(1):28-40.

30. Negrini M, Gramantieri L, Sabbioni S, Croce CM. microRNA involvement in hepatocellular carcinoma. Anticancer Agents Med Chem 2011;11(6):500-521.

31. Hou J, Lin L, Zhou W, et al. Identification of miRNomes in human liver and hepatocellular carcinoma reveals miR-199a/b-3p as therapeutic target for hepatocellular carcinoma. Cancer Cell. 2011;19(2):232-243.

32. Lagos-Quintana M, Rauhut R, Yalcin A, Meyer J, Lendeckel W, Tuschl T. Identification of tissue-specific microRNAs from mouse. Curr Biol. 2002;12(9):735-739.

33. Xu H, He JH, Xiao ZD, et al. Liver-enriched transcription factors regulate microRNA-122 that targets CUTL1 during liver development. Hepatology. 2010;52(4):1431-1442.

34. Esau C, Davis S, Murray SF, et al. miR-122 regulation of lipid metabolism revealed by in vivo antisense targeting. Cell Metab. 2006;3(2): 87-98.

35. Krutzfeldt J, Stoffel M. MicroRNAs: a new class of regulatory genes affecting metabolism. Cell Metab. 2006;4(1):9-12.

36. Bai S, Nasser MW, Wang B, et al. MicroRNA-122 inhibits tumorigenic properties of hepatocellular carcinoma cells and sensitizes these cells to sorafenib. J Biol Chem. 2009;284(46):32015-32027.
37. Ma L, Liu J, Shen J, et al. Expression of miR-122 mediated by adenoviral vector induces apoptosis and cell cycle arrest of cancer cells. Cancer Biol Ther. 2010;9(7):554-561.

38. Fornari F, Gramantieri L, Giovannini C, et al. MiR-122/cyclin G1 interaction modulates p53 activity and affects doxorubicin sensitivity of human hepatocarcinoma cells. Cancer Res. 2009;69(14):5761-5767.

39. Tsai WC, Hsu PW, Lai TC, et al. MicroRNA-122, a tumor suppressor microRNA that regulates intrahepatic metastasis of hepatocellular carcinoma. Hepatology. 2009;49(5):1571-1582.

40. Coulouarn C, Factor VM, Andersen JB, Durkin ME, Thorgeirsson SS. Loss of miR-122 expression in liver cancer correlates with suppression of the hepatic phenotype and gain of metastatic properties. Oncogene. 2009;28(40):3526-3536.

41. Hsu SH, Wang B, Kota J, et al. Essential metabolic, anti-inflammatory, and anti-tumorigenic functions of miR-122 in liver. JClin Invest. 2012;122(8): 2871-2883.

42. Tsai WC, Hsu SD, Hsu CS, et al. MicroRNA-122 plays a critical role in liver homeostasis and hepatocarcinogenesis. J Clin Invest. 2012;122(8): 2884-2897.

43. Gramantieri L, Ferracin M, Fornari F, et al. Cyclin G1 is a target of miR-122a, a microRNA frequently down-regulated in human hepatocellular carcinoma. Cancer Res. 2007;67(13):6092-6099.

44. Jensen MR, Factor VM, Fantozzi A, Helin K, Huh CG, Thorgeirsson SS Reduced hepatic tumor incidence in cyclin G1-deficient mice. Hepatology. 2003;37(4):862-870.

45. Lin CJ, Gong HY, Tseng HC, Wang WL, Wu JL. miR-122 targets an anti-apoptotic gene, Bcl-w, in human hepatocellular carcinoma cell lines. Biochem Biophys Res Commun. 2008;375(3):315-320.

46. Murakami Y, Yasuda T, Saigo K, et al. Comprehensive analysis of microRNA expression patterns in hepatocellular carcinoma and nontumorous tissues. Oncogene. 2006;25(17):2537-2545.

47. Jiang J, Gusev Y, Aderca I, et al. Association of MicroRNA expression in hepatocellular carcinomas with hepatitis infection, cirrhosis, and patient survival. Clin Cancer Res. 2008;14(2):419-427.

48. Jia XQ, Cheng HQ, Qian X, et al. Lentivirus-mediated overexpression of microRNA-199a inhibits cell proliferation of human hepatocellular carcinoma. Cell Biochem Biophys. 2012;62(1):237-244.

49. Fornari F, Milazzo M, Chieco P, et al. MiR-199a-3p regulates mTOR and c-Met to influence the doxorubicin sensitivity of human hepatocarcinoma cells. Cancer Res. 2010;70(12):5184-5193.

50. Kim S, Lee UJ, Kim MN, et al. MicroRNA miR-199a* regulates the MET proto-oncogene and the downstream extracellular signal-regulated kinase 2 (ERK2). J Biol Chem. 2008;283(26):18158-18166.

51. Wang C, Song B, Song W, et al. Underexpressed microRNA-199b-5p targets hypoxia-inducible factor-1alpha in hepatocellular carcinoma and predicts prognosis of hepatocellular carcinoma patients. J Gastroenterol Hepatol. 2011;26(11):1630-1637.

52. Henry JC, Park JK, Jiang J, et al. miR-199a-3p targets CD44 and reduces proliferation of CD44 positive hepatocellular carcinoma cell lines. Biochem Biophys Res Commun. 2010;403(1):120-125.

53. Shen Q, Cicinnati VR, Zhang X, et al. Role of microRNA-199a-5p and discoidin domain receptor 1 in human hepatocellular carcinoma invasion. Mol Cancer. 2010;9:227.

54. Fornari F, Gramantieri L, Ferracin M, et al. MiR-221 controls CDKN1C/ p57 and CDKN1B/p27 expression in human hepatocellular carcinoma. Oncogene. 2008;27(43):5651-5661.

55. Medina R, Zaidi SK, Liu CG, et al. MicroRNAs 221 and 222 bypass quiescence and compromise cell survival. Cancer Res. 2008;68(8):2773-2780.

56. Garofalo M, Di Leva G, Romano G, et al. miR-221 and 222 regulate TRAIL resistance and enhance tumorigenicity through PTEN and TIMP3 downregulation. Cancer Cell. 2009;16(6):498-509.

57. Pineau P, Volinia S, McJunkin K, et al. miR-221 overexpression contributes to liver tumorigenesis. Proc Natl Acad Sci USA. 2010;107(1): 264-269.

58. Callegari E, Elamin BK, Giannone F, et al. Liver tumorigenicity promoted by microRNA-221 in a mouse transgenic model. Hepatology. 2012;56(3):1025-1033. 
59. Gramantieri L, Fornari F, Ferracin M, et al. MicroRNA-221 targets Bmf in hepatocellular carcinoma and correlates with tumor multifocality. Clin Cancer Res. 2009;15(16):5073-5081.

60. Volinia S, Calin GA, Liu CG, et al. A microRNA expression signature of human solid tumors defines cancer gene targets. Proc Natl Acad Sci US A. 2006;103(7):2257-2261.

61. Chan JA, Krichevsky AM, Kosik KS. MicroRNA-21 is an antiapoptotic factor in human glioblastoma cells. Cancer Res. 2005;65(14): 6029-6033.

62. Si ML, Zhu S, Wu H, Lu Z, Wu F, Mo YY. miR-21-mediated tumor growth. Oncogene. 2007;26(19):2799-2803.

63. Buscaglia LE, Li Y. Apoptosis and the target genes of microRNA-21. Chin J Cancer. 2011;30(6):371-380.

64. Meng F, Henson R, Wehbe-Janek H, Ghoshal K, Jacob ST, Patel T. MicroRNA-21 regulates expression of the PTEN tumor suppressor gene in human hepatocellular cancer. Gastroenterology. 2007;133(2):647-658.

65. Asangani IA, Rasheed SA, Nikolova DA, et al. MicroRNA-21 (miR-21) post-transcriptionally downregulates tumor suppressor Pdcd4 and stimulates invasion, intravasation and metastasis in colorectal cancer. Oncogene. 2008;27(15):2128-2236.

66. Frankel LB, Christoffersen NR, Jacobsen A, Lindow M, Krogh A, Lund AH. Programmed cell death 4 (PDCD4) is an important functional target of the microRNA miR-21 in breast cancer cells. J Biol Chem. 2008;283(2):1026-1033.

67. Ferracin M, Veronese A, Negrini M. Micromarkers: miRNAs in cancer diagnosis and prognosis. Expert Rev Mol Diagn. 2010;10(3): 297-308.

68. Minguez B, Lachenmayer A. Diagnostic and prognostic molecular markers in hepatocellular carcinoma. Dis Markers. 2011;31(3):181-190.

69. Barshack I, Meiri E, Rosenwald S, et al. Differential diagnosis of hepatocellular carcinoma from metastatic tumors in the liver using microRNA expression. Int J Biochem Cell Biol. 2010;42(8):1355-1362.

70. Hess KR, Varadhachary GR, Taylor SH, et al. Metastatic patterns in adenocarcinoma. Cancer. 2006;106(7):1624-1633.

71. Cortez MA, Calin GA. MicroRNA identification in plasma and serum: a new tool to diagnose and monitor diseases. Expert Opin Biol Ther. 2009;9(6):703-711.

72. Qi J, Wang J, Katayama H, Sen S, Liu SM. Circulating microRNAs (cmiRNAs) as novel potential biomarkers for hepatocellular carcinoma. Neoplasma. November 12, 2013;60(2):135-42.

73. Xu J, Wu C, Che X, et al. Circulating microRNAs, miR-21, miR-122, and miR-223, in patients with hepatocellular carcinoma or chronic hepatitis. Mol Carcinog. 2011;50(2):136-142.

74. Cermelli S, Ruggieri A, Marrero JA, Ioannou GN, Beretta L. Circulating microRNAs in patients with chronic hepatitis $\mathrm{C}$ and non-alcoholic fatty liver disease. PLoS One. 2011;6(8):e23937.

75. Tomimaru Y, Eguchi H, Nagano H, et al. Circulating microRNA-21 as a novel biomarker for hepatocellular carcinoma. J Hepatol. 2012;56(1): $167-175$.

76. Trebicka J, Anadol E, Elfimova N, et al. Hepatic and serum levels of miR122 after chronic HCV-induced fibrosis. J Hepatol. 2013;58(2):234-239.

77. van der Meer AJ, Farid WR, Sonneveld MJ, et al. Sensitive detection of hepatocellular injury in chronic hepatitis $\mathrm{C}$ patients with circulating hepatocyte-derived microRNA-122. J Viral Hepat. 2013;20(3): $158-166$.

78. Krutzfeldt J, Rajewsky N, Braich R, et al. Silencing of microRNAs in vivo with 'antagomirs'. Nature. 2005;438(7068):685-689.

79. Elmen J, Lindow M, Schutz S, et al. LNA-mediated microRNA silencing in non-human primates. Nature. 2008;452(7189):896-899.

80. Mercatelli N, Coppola V, Bonci D, et al. The inhibition of the highly expressed miR-221 and miR-222 impairs the growth of prostate carcinoma xenografts in mice. PLoS One. 2008;3(12):e4029.

81. Felicetti F, Errico MC, Bottero L, et al. The promyelocytic leukemia zinc finger-microRNA-221/-222 pathway controls melanoma progression through multiple oncogenic mechanisms. Cancer Res. 2008;68(8): 2745-2754.
82. Di Martino MT, Gulla A, Cantafio ME, et al. In vitro and in vivo anti-tumor activity of miR-221/222 inhibitors in multiple myeloma. Oncotarget. 2013;4(2):242-255.

83. Park JK, Kogure T, Nuovo GJ, et al. miR-221 silencing blocks hepatocellular carcinoma and promotes survival. Cancer Res. 2011;71(24): 7608-7616.

84. Leone E, Morelli E, Di Martino MT, et al. Targeting miR-21 inhibits in vitro and in vivo multiple myeloma cell growth. Clin Cancer Res. 2013;19(8):2096-2106.

85. Lindow M, Kauppinen S. Discovering the first microRNA-targeted drug. J Cell Biol. 2012;199(3):407-412.

86. Lanford RE, Hildebrandt-Eriksen ES, Petri A, et al. Therapeutic silencing of microRNA-122 in primates with chronic hepatitis $\mathrm{C}$ virus infection. Science. 2010;327(5962):198-201.

87. Hildebrandt-Eriksen ES, Aarup V, Persson R, Hansen HF, Munk ME, Orum H. A locked nucleic acid oligonucleotide targeting microRNA 122 is well-tolerated in cynomolgus monkeys. Nucleic Acid Ther. 2012;22(3):152-161.

88. Kota J, Chivukula RR, O'Donnell KA, et al. Therapeutic microRNA delivery suppresses tumorigenesis in a murine liver cancer model. Cell. 2009;137(6):1005-1017.

89. He XX, Chang Y, Meng FY, et al. MicroRNA-375 targets AEG-1 in hepatocellular carcinoma and suppresses liver cancer cell growth in vitro and in vivo. Oncogene. 2012;31(28):3357-3369.

90. Xiong Y, Fang JH, Yun JP, et al. Effects of microRNA-29 on apoptosis, tumorigenicity, and prognosis of hepatocellular carcinoma. Hepatology. 2010;51(3):836-845.

91. Akao Y, Nakagawa Y, Hirata I, et al. Role of anti-oncomirs miR-143 and -145 in human colorectal tumors. Cancer Gene Ther. 2010;17(6): 398-408.

92. Kitade Y, Akao Y. MicroRNAs and their therapeutic potential for human diseases: microRNAs, miR-143 and -145, function as antioncomirs and the application of chemically modified miR-143 as an anti-cancer drug. J Pharmacol Sci. 2010;114(3):276-280.

93. Ibrahim AF, Weirauch U, Thomas M, Grunweller A, Hartmann RK, Aigner A. MicroRNA replacement therapy for miR-145 and miR-33a is efficacious in a model of colon carcinoma. Cancer Res. 2011;71(15): 5214-5224.

94. Valastyan S, Chang A, Benaich N, Reinhardt F, Weinberg RA. Activation of miR-31 function in already-established metastases elicits metastatic regression. Genes Dev. 2011;25(6):646-659.

95. Bader AG. miR-34 - a microRNA replacement therapy is headed to the clinic. Front Genet. 2012;3:120.

96. Kasinski AL, Slack FJ. miRNA-34 prevents cancer initiation and progression in a therapeutically resistant K-ras and p53-induced mouse model of lung adenocarcinoma. Cancer Res. 2012;72(21): 5576-5587.

97. Di Martino MT, Leone E, Amodio N, et al. Synthetic miR-34a mimics as a novel therapeutic agent for multiple myeloma: in vitro and in vivo evidence. Clin Cancer Res. 2012;18(22):6260-6270.

98. Lou W, Chen Q, Ma L, et al. Oncolytic adenovirus co-expressing miRNA-34a and IL-24 induces superior antitumor activity in experimental tumor model. J Mol Med (Berl). 2013;91(6):715-725.

99. Bischoff JR, Kirn DH, Williams A, et al. An adenovirus mutant that replicates selectively in p53-deficient human tumor cells. Science. 1996;274(5286):373-376.

100. Mathis JM, Stoff-Khalili MA, Curiel DT. Oncolytic adenoviruses - selective retargeting to tumor cells. Oncogene. 2005;24(52):7775-7791.

101. Alemany R. Cancer selective adenoviruses. MolAspects Med. 2007;28(1): 42-58.

102. Ganly I, Kirn D, Eckhardt G, et al. A phase I study of Onyx-015, an E1B attenuated adenovirus, administered intratumorally to patients with recurrent head and neck cancer. Clin Cancer Res. 2000;6(3):798-806.

103. Nemunaitis J, Ganly I, Khuri F, et al. Selective replication and oncolysis in p53 mutant tumors with ONYX-015, an E1B-55kD genedeleted adenovirus, in patients with advanced head and neck cancer: a phase II trial. Cancer Res. 2000;60(22):6359-6366. 
104. Galanis E, Okuno SH, Nascimento AG, et al. Phase I-II trial of ONYX-015 in combination with MAP chemotherapy in patients with advanced sarcomas. Gene Ther. 2005;12(5):437-445.

105. Opyrchal M, Aderca I, Galanis E. Phase I clinical trial of locoregional administration of the oncolytic adenovirus ONYX-015 in combination with mitomycin-C, doxorubicin, and cisplatin chemotherapy in patients with advanced sarcomas. Methods Mol Biol. 2009;542:705-717.

106. Khuri FR, Nemunaitis J, Ganly I, et al. A controlled trial of intratumoral ONYX-015, a selectively-replicating adenovirus, in combination with cisplatin and 5-fluorouracil in patients with recurrent head and neck cancer. Nat Med. 2000;6(8):879-885.

107. Nemunaitis J, Swisher SG, Timmons T, et al. Adenovirus-mediated p53 gene transfer in sequence with cisplatin to tumors of patients with non-small-cell lung cancer. J Clin Oncol. 2000;18(3):609-622.

108. Patel MR, Kratzke RA. Oncolytic virus therapy for cancer: the first wave of translational clinical trials. Transl Res. 2013;161(4):355-364.

109. Hu JC, Coffin RS, Davis CJ, et al. A phase I study of OncoVEXGM$\mathrm{CSF}$, a second-generation oncolytic herpes simplex virus expressing granulocyte macrophage colony-stimulating factor. Clin Cancer Res. 2006;12(22):6737-6747.

110. Harrington KJ, Hingorani M, Tanay MA, et al. Phase I/II study of oncolytic HSV GM-CSF in combination with radiotherapy and cisplatin in untreated stage III/IV squamous cell cancer of the head and neck. Clin Cancer Res. 2010;16(15):4005-4015.

111. Cerullo V, Pesonen S, Diaconu I, et al. Oncolytic adenovirus coding for granulocyte macrophage colony-stimulating factor induces antitumoral immunity in cancer patients. Cancer Res. 2010;70(11):4297-4309.

112. Pesonen S, Diaconu I, Cerullo V, et al. Integrin targeted oncolytic adenoviruses Ad5-D24-RGD and Ad5-RGD-D24-GMCSF for treatment of patients with advanced chemotherapy refractory solid tumors. Int J Cancer. 2012;130(8):1937-1947.

113. Kanerva A, Nokisalmi P, Diaconu I, et al. Anti-viral and anti-tumor T-cell immunity in patients treated with GMCSF coding oncolytic adenovirus. Clin Cancer Res. 2013;19(10):2734-2744.

114. Park BH, Hwang T, Liu TC, et al. Use of a targeted oncolytic poxvirus, JX-594, in patients with refractory primary or metastatic liver cancer: a phase I trial. Lancet Oncol. 2008;9(6):533-542.

115. Hwang TH, Moon A, Burke J, et al. A mechanistic proof-ofconcept clinical trial with JX-594, a targeted multi-mechanistic oncolytic poxvirus, in patients with metastatic melanoma. Mol Ther. 2011;19(10):1913-

116. Heo J, Reid T, Ruo L, et al. Randomized dose-finding clinical trial of oncolytic immunotherapeutic vaccinia JX-594 in liver cancer. Nat Med. 2013;19(3):329-336.

117. Kelly EJ, Hadac EM, Greiner S, Russell SJ. Engineering microRNA responsiveness to decrease virus pathogenicity. Nat Med. 2008;14(11): 1278-1283.

118. Ylosmaki E, Hakkarainen T, Hemminki A, Visakorpi T, Andino R, Saksela K. Generation of a conditionally replicating adenovirus based on targeted destruction of E1A mRNA by a cell type-specific MicroRNA. J Virol. 2008;82(22):11009-11015.

119. Ylosmaki E, Lavilla-Alonso S, Jaamaa S, et al. MicroRNA-mediated suppression of oncolytic adenovirus replication in human liver. PLoS One. 2013;8(1):e54506.

120. Cawood R, Chen HH, Carroll F, Bazan-Peregrino M, van Rooijen N, Seymour LW. Use of tissue-specific microRNA to control pathology of wild-type adenovirus without attenuation of its ability to kill cancer cells. PLoS Pathog. 2009;5(5):e1000440.

121. Cawood R, Wong SL, Di Y, Baban DF, Seymour LW. MicroRNA controlled adenovirus mediates anti-cancer efficacy without affecting endogenous microRNA activity. PLoS One. 2011;6(1):e16152.

122. Leja J, Nilsson B, Yu D, et al. Double-detargeted oncolytic adenovirus shows replication arrest in liver cells and retains neuroendocrine cell killing ability. PLoS One. 2010;5(1):e8916.

123. Jin H, Lv S, Yang J, et al. Use of microRNA Let-7 to control the replication specificity of oncolytic adenovirus in hepatocellular carcinoma cells. PLoS One. 2011;6(7):e21307.
124. Nguyen LV, Vanner R, Dirks P, Eaves CJ. Cancer stem cells: an evolving concept. Nat Rev Cancer. 2012;12(2):133-143.

125. Suh MR, Lee Y, Kim JY, et al. Human embryonic stem cells express a unique set of microRNAs. Dev Biol. 2004;270(2):488-498.

126. Hatfield SD, Shcherbata HR, Fischer KA, Nakahara K, Carthew RW, Ruohola-Baker H. Stem cell division is regulated by the microRNA pathway. Nature. 2005;435(7044):974-978.

127. Ma S. Biology and clinical implications of CD133(+) liver cancer stem cells. Exp Cell Res. 2013;319(2):126-132.

128. Oishi N, Wang XW. Novel therapeutic strategies for targeting liver cancer stem cells. Int J Biol Sci. 2011;7(5):517-535.

129. Lee TK, Cheung VC, Ng IO. Liver tumor-initiating cells as a therapeutic target for hepatocellular carcinoma. Cancer Lett. 2012. May 8, 2013. [Epub ahead of print.]

130. Pang RW, Poon RT. Cancer stem cell as a potential therapeutic target in hepatocellular carcinoma. Curr Cancer Drug Targets. 2012;12(9): 1081-1094.

131. Budhu A, Jia HL, Forgues M, et al. Identification of metastasis-related microRNAs in hepatocellular carcinoma. Hepatology. 2008;47(3): 897-907.

132. Han ZB, Zhong L, Teng MJ, et al. Identification of recurrencerelated microRNAs in hepatocellular carcinoma following liver transplantation. Mol Oncol. 2012;6(4):445-457.

133. Ji J, Shi J, BudhuA, et al. MicroRNA expression, survival, and response to interferon in liver cancer. N Engl J Med. 2009;361(15):1437-1447.

134. Viswanathan SR, Powers JT, Einhorn W, et al. Lin 28 promotes transformation and is associated with advanced human malignancies. Nat Genet. 2009;41(7):843-848.

135. Zhang Y, Guo X, Xiong L, et al. MicroRNA-101 suppresses SOX9-dependent tumorigenicity and promotes favorable prognosis of human hepatocellular carcinoma. FEBS Lett. 2012;586(24): 4362-4370.

136. Li W, Xie L, He X, et al. Diagnostic and prognostic implications of microRNAs in human hepatocellular carcinoma. Int $J$ Cancer. 2008;123(7):1616-1622.

137. Gu H, Guo X, Zou L, Zhu H, Zhang J. Upregulation of microRNA372 associates with tumor progression and prognosis in hepatocellular carcinoma. Mol Cell Biochem. 2013;375(1-2):23-30.

138. Fu X, Wang Q, Chen J, et al. Clinical significance of miR-221 and its inverse correlation with p27 Kip(1) in hepatocellular carcinoma. Mol Biol Rep. 2011;38(5):3029-3035.

139. Rong M, Chen G, Dang Y. Increased miR-221 expression in hepatocellular carcinoma tissues and its role in enhancing cell growth and inhibiting apoptosis in vitro. BMC Cancer. 2013;13:21.

140. Chen L, Jiang M, Yuan W, Tang H. miR-17-5p as a novel prognostic marker for hepatocellular carcinoma. J Invest Surg. 2012;25(3): 156-161.

141. Han ZB, Chen HY, Fan JW, Wu JY, Tang HM, Peng ZH. Upregulation of microRNA-155 promotes cancer cell invasion and predicts poor survival of hepatocellular carcinoma following liver transplantation. J Cancer Res Clin Oncol. 2012;138(1):153-161.

142. Chen HY, Han ZB, Fan JW, et al. miR-203 expression predicts outcome after liver transplantation for hepatocellular carcinoma in cirrhotic liver. Med Oncol. 2012;29(3):1859-1865.

143. Murakami Y, Tamori A, Itami S, et al. The expression level of miR-18b in hepatocellular carcinoma is associated with the grade of malignancy and prognosis. BMC Cancer. 2013;13:99.

144. Xu J, Zhu X, Wu L, et al. MicroRNA-122 suppresses cell proliferation and induces cell apoptosis in hepatocellular carcinoma by directly targeting Wnt/beta-catenin pathway. Liver Int. 2012;32(5): 752-760.

145. Qi P, Cheng SQ, Wang H, Li N, Chen YF, Gao CF. Serum microRNAs as biomarkers for hepatocellular carcinoma in Chinese patients with chronic hepatitis B virus infection. PLoS One. 2011;6(12):e28486.

146. Li J, Wang Y, Yu W, Chen J, Luo J. Expression of serum miR-221 in human hepatocellular carcinoma and its prognostic significance. Biochem Biophys Res Commun. 2011;406(1):70-73. 
147. Gui J, Tian Y, Wen X, et al. Serum microRNA characterization identifies miR-885-5p as a potential marker for detecting liver pathologies. Clin Sci (Lond). 2011;120(5):183-193.

148. Liu AM, Yao TJ, Wang W, et al. Circulating miR-15b and miR-130b in serum as potential markers for detecting hepatocellular carcinoma: a retrospective cohort study. BMJ Open. 2012;2(2):e000825.

149. Shrivastava S, Petrone J, Steele R, Lauer GM, Bisceglie AM, Ray RB. Upregulation of circulating miR-20a is correlated with hepatitis $\mathrm{C}$ virus mediated liver disease progression. Hepatology. February 6, 2013. [Epub ahead of print.]

150. Ji J, Yamashita T, Budhu A, et al. Identification of microRNA-181 by genome-wide screening as a critical player in EpCAM-positive hepatic cancer stem cells. Hepatology. 2009;50(2):472-480.

151. Ji J, Yamashita T, Wang XW. Wnt/beta-catenin signaling activates microRNA-181 expression in hepatocellular carcinoma. Cell Biosci. 2011;1(1):4.

152. Xu C, Liu S, Fu H, et al. MicroRNA-193b regulates proliferation, migration and invasion in human hepatocellular carcinoma cells. Eur $J$ Cancer. 2010;46(15):2828-2836.

153. Ma S, Tang KH, Chan YP, et al. miR-130b promotes CD133(+) liver tumor-initiating cell growth and self-renewal via tumor protein 53-induced nuclear protein 1. Cell Stem Cell. 2010;7(6):694-707.

154. Jung CJ, Iyengar S, Blahnik KR, et al. Epigenetic modulation of miR122 facilitates human embryonic stem cell self-renewal and hepatocellular carcinoma proliferation. PLoS One. 2011;6(11):e27740.
155. Jia Y, Liu H, Zhuang Q, et al. Tumorigenicity of cancer stem-like cells derived from hepatocarcinoma is regulated by microRNA-145. Oncol Rep. 2012;27(6):1865-1872.

156. Zhang J, Luo N, Luo Y, Peng Z, Zhang T, Li S. microRNA-150 inhibits human CD133-positive liver cancer stem cells through negative regulation of the transcription factor c-Myb. Int J Oncol. 2012;40(3): $747-756$.

157. Oishi N, Kumar MR, Roessler S, et al. Transcriptomic profiling reveals hepatic stem-like gene signatures and interplay of miR-200c and epithelial-mesenchymal transition in intrahepatic cholangiocarcinoma. Hepatology. 2012;56(5):1792-1803.

158. Wu K, Ding J, Chen C, et al. Hepatic transforming growth factor beta gives rise to tumor-initiating cells and promotes liver cancer development. Hepatology. 2012;56(6):2255-2267.

159. Xia H, Ooi LL, Hui KM. MiR-216a/217-induced epithelialmesenchymal transition targets PTEN and SMAD7 to promote drug resistance and recurrence of liver cancer. Hepatology. March 7, 2013. [Epub ahead of print.]

160. Xia H, Ooi LL, Hui KM. MiR-214 targets beta-catenin pathway to suppress invasion, stem-like traits and recurrence of human hepatocellular carcinoma. PLoS One. 2012;7(9):e44206.
OncoTargets and Therapy

\section{Publish your work in this journal}

OncoTargets and Therapy is an international, peer-reviewed, open access journal focusing on the pathological basis of all cancers, potential targets for therapy and treatment protocols employed to improve the management of cancer patients. The journal also focuses on the impact of management programs and new therapeutic agents and protocols on

\section{Dovepress}

patient perspectives such as quality of life, adherence and satisfaction The manuscript management system is completely online and includes a very quick and fair peer-review system, which is all easy to use. Visit http://www.dovepress.com/testimonials.php to read real quotes from published authors. 